\title{
TRT Çocuk Kanalında Yayınlanan Çizgi Filmlerin Gelişim Alanlarına Göre Değerlendirilmesi*
}

\section{Evaluation of Cartoons Broadcasted in TRT Children's Channel According to Development Areas}

\author{
Özge CENGİZ**, Gülşen İLÇİ KÜSMÜŞ***, M. Oya RAMAZAN****
}

Öz: Bu araştırmada TRT Çocuk Kanalı'nda yayınlanan çizgi filmlerin kazanım ve göstergelere göre değerlendirilmesi amaçlanmıştır. Çalışma grubu "Kuzucuk", "Kare" ve "Ege ile Gaga" adlı çizgi filmlerin 30 bölümünden oluşmaktadır. İncelenen çizgi film bölümlerinde hangi gelişim alanlarına ne kadar sıklıkla yer verildiği belirlenmiştir. Araştırma sonucunda "Kuzucuk" çizgi filminde Bilişsel Gelişim alanındaki kazanımlardan en çok K17'ye; Sosyal ve Duygusal Gelişim alanındakilerden en çok K5'e; Dil Gelişimi alanındakilerden en çok K5'e yer verildiği görülmüştür. Motor Gelişim alanındaki kazanımlara bu çizgi filmde rastlanmamıştır. Öz Bakım Becerilerine yönelik 8 kazanımdan 5'ine 1'er kez yer verildiği bulunmuştur. "Ege ile Gaga" çizgi filminde Bilişsel Gelişim alanındaki kazanımlardan en çok K1 ve K2'ye; Sosyal ve Duygusal Gelişim alanındakilerden en çok K5'e; Dil Gelişimi alanındakilerden en çok K5'e yer verildiği belirlenmiştir. Motor Gelişim alanına yönelik kazanımlara bu çizgi filmde de rastlanmamıştır. Öz Bakım becerilerine yönelik ise sadece 1 kazanıma (K7) 2 kez rastlanmıştır. "Kare" çizgi filminde Bilişsel Gelişim alanındaki kazanımlardan en çok K8'e; Sosyal ve Duygusal Gelişim alanındakilerden en çok K5'e; Dil Gelişimi alanındakilerden en çok K5'e yer verildiği bulunmuştur. "Kare" çizgi filminde Motor Gelişimine yönelik 5 kazanımdan 2'sine 1'er kez (K1 ve K2) rastlanmıştır. Öz Bakım becerilerine yönelik ise bu çizgi filmde de sadece 1 kazanıma (K3) rastlanmıştır.

Anahtar Kelimeler: Okul öncesi dönem, çocuk kanalı, çizgi filmler, değerlendirme, gelişim alanları, kazanım ve göstergeler

\begin{abstract}
In this study, it was aimed to evaluate the cartoons broadcasted in TRT Children's Channel according to learning outcomes and indicators. The study group consists of 30 sections of "Kuzucuk", "Kare" and "Ege ve Gaga" cartoons. It was determined how often the developmental areas were included in the cartoon sections examined. As a result of the research, in the cartoon "Kuzucuk", it is determined that most of the learning outcomes in Cognitive Development are K17; that of Social and Emotional Development are K5; that of Language Development are K5. The learning outcomes in the field of Motor Development are not included in this cartoon. It was found that 5 out of 8 learning outcomes for Self Care Skills were included once. In the cartoon "Ege ile Gaga", it is determined that most of the learning outcomes in Cognitive Development are K1 and K2; that of Social and Emotional Development are K5; that of Language Development are K5. The learning outcomes of the Motor Development area were not found in this cartoon. As for Self Care Skills, only 1 learning outcomes (K7) was found twice. In the cartoon "Kare", it is determined that most of the learning outcomes in Cognitive Development are K8; that of Social and Emotional Development are K5; that of Language Development are K5. In the cartoon "Kare", 2 out of 5 learning outcomes for Motor Development were encountered once (K1 and K2) and only 1 learning outcome (K3) of Self Care Skills was found.
\end{abstract}

Keywords: Preschool period, children's channel, cartoons, evaluation, development areas, learning outcomes and indicators.

\footnotetext{
* Bu çalışma 2-5 Ekim 2019 tarihleri arasında Kafkas Üniversitesi’nde düzenlenen 6. Uluslararası Okul Öncesi Eğitimi Kongresi'nde sözlü bildiri olarak sunulmuştur.

** Arş. Gör., Marmara Üniversitesi, Atatürk Eğitim Fakültesi, İstanbul-Türkiye, ORCID: 0000-0003-0628-3825, e-posta: ozge.cengiz@marmara.edu.tr

*** Arş. Gör., Marmara Üniversitesi, Atatürk Eğitim Fakültesi, İstanbul-Türkiye, ORCID: 0000-0003-2885-1176, e-posta: gulsen.ilci@ marmara.edu.tr

**** Doç. Dr., Marmara Üniversitesi, Atatürk Eğitim Fakültesi, İstanbul-Türkiye, ORCID: 0000-0001-9974-4568,

e-posta: oramazan@marmara.edu.tr
} 


\section{Giriş}

Yaşamın ilk altı yılını içine alan okul öncesi dönem; beyin gelişiminin ve sinaptik bağlantıların çok hızlı ve yoğun yaşandığı bir dönemdir. Beyin gelişimi tüm gelişim alanlarını etkiler ve çocukların bilişsel, dil, motor, sosyal ve duygusal gelişimi için güçlü bir zemin oluşturur. $\mathrm{Bu}$ zemin sayesinde çocukların potansiyellerini açığa çıkarma ve üretken bireyler olabilmelerinin yolu açılmaktadır. Beyin gelişimi için ise çevresel etkiler ön plana çıkmaktadır (MEB, 2013).

Çocuklar içinde bulundukları çevre ile etkileşim içindedirler. Potansiyellerini ortaya çıkarmada çevrenin etkisi büyüktür. Çünkü çevrenin çocuğa sunduğu olanaklar ile keşfetmesi, öğrenme çeşidi ve hızı yakından ilişkilidir. Çocuğun gelişimi için gerekli zengin uyarıcı ortam ve zengin öğrenme olanaklarının sunulduğu yerler ise okul öncesi eğitim kurumlarıdır (MEB, 2013; Woolfolk, 1998).

Çocuğun gelişim sürecinde çevresel etmenlerin yanı sıra toplumsal değişkenler de etkilidir. Günümüzde toplumsal değişkenlerin içinde de kitle iletişim araçları ön plana çıkmaktadır (İnanl1, 2008). Kitle iletişim araçlarından biri olan televizyon, geniş kitlelere kolayca ulaşması bakımından önemlidir. Teknolojinin gelişmesi sonucu internetin bulunuşu ile her ne kadar televizyonun etkisi azalsa da eğlendiriciliği, verdiği mesajlarla kitlelere ulaşması, bu sayede kitleleri eğitmesi ve yönlendirmesiyle yaygınlığı hala devam etmektedir (Ünal ve Durualp, 2012).

En yaygın ve etkili kitle iletişim aracı olan televizyondan etkilenen kitle içinde çocuklar da yer almaktadır. Okul öncesi dönemde çocukların televizyondan etkilenme düzeyleri; yaşlarına, gelişimlerine, ailesel ve çevresel faktörlerine, izledikleri programların içeriklerine göre değişmektedir (Büyükbaykal, 2007). Çocukları diğer iletişim araçlarına kıyasla cezbeden ve kendine çeken televizyon, aynı zamanda görselliğe de hitap etmesiyle, çocuklar için dikkat çeken bir uyarıcı hükmündedir (Şirin, 1999; Yapıc1, 2006). Türkiye İstatistik Kurumu 2013 verilerine bakıldığında; 6-15 yaş grubundaki çocukların \%92,5'inin, 6-10 yaş grubundaki çocukların $\% 94,8$ 'inin ve $11-15$ yaş grubu çocuklarda ise \%90,2'sinin hemen her gün TV izlediği ortaya çıkmış, 6-10 yaş grubu çocukların en çok izlediği program türünün çizgi filmler olduğu belirtilmiştir (TÜİK, 2013). Benzer olarak bir başka çalışmada 10 yaşına kadar çocukların en sevdiği program türünün çizgi filmler olduğu belirlenmiştir (Cesur ve Paker, 2007).

Televizyonun çocuklar üzerindeki etkileri göz önünde bulundurulduğunda bu durumun aynı zamanda çocukların gelişim alanlarını da etkileyebileceği düşünülmektedir. Televizyonun çocuklar üzerinde olumlu ve olumsuz birçok etkisi bulunmaktadır. Bu etkiler çocukların gelişim alanlarını da etkilemektedir (Kurt, 2014). Programlar eğitsel içerikli olduğunda çocuk gelişimi açısından olumlu etkileri olduğu belirtilmektedir (Serhatlığlu, 2006). Programlar kontrollü ve doğru biçimde hazırlandığında; çocuklara kavram öğretimi, milli manevi değerlerin öğretimi, okula hazırlık, dil gelişimi, yeni kelime ve kavram öğretimi gibi konularda olumlu etkiler sağlamaktadır (Günaydın, 2011). Yine yapılan çalışmalarda okul öncesi dönem çocuklarının görsel, bilişsel ve sosyal gelişimine televizyonun katkı sağladığı belirtilmiştir (Önder ve Balaban Dağal, 2005a; Straker, Pollock, Zubrick ve Kurinczuk, 2006).

Olumlu etkilerin yanı sıra televizyonun çocuk gelişimi üzerine olumsuz etkileri de bulunmaktadır. Sosyal ve duygusal gelişim açısından; iletişimi engelleyebilmekte, çünkü çocuk televizyona soru soramamakta, açıklama isteyememekte ve itiraz edememektedir (Avc1, 2010; Balaban, 2002; Gülşen, 2006). Bilişsel gelişim açısından; televizyon çocukların düşünme, analiz etme, değerlendirme ve çıkarımlarda bulunma gibi zihinsel becerilerini sınırlandırmaktadır (Öztürk, 2002). Televizyondaki hızla akan görüntüler nedeniyle çocuklarda dikkat dağınıklığı ve konsantrasyon bozukluğu olabilmekte ve bu da çocukların dil gelişimini etkilemektedir. Bunun sonucu olarak da geç konuşma ya da cümle kuramama gibi durumlarla karşılaşılabilmektedir (Büyükbaykal, 2007). Motor gelişim açısından; 2-7 yaş aralığındaki çocukların fiziksel gelişimlerinden yola çıkarak; sürekli koşup oynaması ve çok hareketli olması beklenen çocukların televizyon karşısında uzun süre hareketsiz oturması, fiziksel gelişimlerinde olumsuz etki oluşturabilmektedir (Özkan ve Yılmaz, 2016). Nitekim yapılan bir araştırmada uzun süre televizyon seyretmenin çocuklarda yüksek düzeyde duygusal kararsızlık, saldırganlık ve obezite, düşük düzeyde uyum, deneyime açıklık ve dürüstlük gibi sonuçlar elde edilmiştir (Persegani ve diğerleri, 2002). 
Okul öncesi dönem çocukları ve çizgi filmler üzerine yapılan araştırmalar incelendiğinde; Aydın'ın (2018) araştırmasında televizyon kanallarındaki çizgi filmlerin çocukluğa etkileri incelenmiştir. Sözü edilen araştırmada Disney Channel ve TRT Çocuk kanallarında yayınlanan 6 çizgi film ele alınmış, bu çizgi filmlerin verdikleri mesajlar ortaya konulmuştur. Araştırma sonuçlarına göre yabancı kaynaklı çizgi filmlerde çocuklara yönelik olarak sevgi, saygı gibi evrensel değerlerin yanı sıra aşırı tüketim, bireyselleşme gibi mesajlar da yer almaktadır. Ayrıca çalışmada TRT Çocuk Kanalı'ndaki yayınların yabancı kaynaklı yayınlara göre sayıca daha yetersiz oldukları belirtilmiştir. Hamarat, Işıtan, Özcan ve Karaşahin (2015) Caillou ve Sünger Bob adlı çizgi filmlerin çocukların gelişimleri açısından uygun olup olmadıklarını belirlemeye çalışmıştır. Araştırma sonucunda konu ve plan açısından değerlendirilen bu iki çizgi film arasından Caillou'nun Sünger Bob'a göre daha fazla olumlu özelliğe sahip olduğu belirlenmiștir. Sünger Bob'un günlük yaşamdan uzak bir kurguya sahip olduğu, Caillou'nun ise çocuğun günlük hayatında karşılaşabileceği olaylar üzerinden kurgulandığı sonucuna ulaşılmıştır. Cebeci ve Demir (2018) 4-6 yaş grubu çocukların çizgi filmlerden etkilenme durumlarını incelemişlerdir. $\mathrm{Bu}$ amaçla araştırmada Rafadan Tayda ve Doraemon çizgi filmlerinin bazı bölümleri içerik açısından ele alınmıştır. Araştırma sonuçlarına göre her iki çizgi filmde de nezaket, arkadaşlık, dostluk kavramları üzerinde durulmuştur. Rafadan Tayfa'da çocuklara yardımlaşma, dayanışma gibi değerlerin önemi de sunulmuştur. Doraemon çizgi filminde ise çocuklara olumsuz örnek teşkil edebilecek bazı unsurların (sihir/büyü gibi) yer aldığı araştırmada belirtilmiştir. Yılmaz ve Çelik (2018) araştırmalarında Niloya ve Kuzucuk çizgi filmlerindeki spor unsurlarını incelemişlerdir. Araştırma sonuçlarına göre her iki çizgi filmde de spor branşlarına, sporla ilgili kavramlara ve terimlere yer verilmiştir. Buna ek olarak söz konusu çizgi film bölümlerinde yarışlarda sportmence rekabet etmenin de önemi üzerinde durulduğu belirlenmiştir.

Yapılan diğer araştırmalar incelendiğinde çizgi filmleri değerler eğitimi (Akıncı ve Güven, 2014; Karakuş, 2015; Özyürek, Kaya, Yeşil ve Karadaş, 2018); kavram gelişimi (Coşkun ve Köroğlu, 2016; Pekşen Akça ve Baran, 2018); verilen eğitimsel ve subliminal mesajlar (Demiral, Yamaner ve Süklüm, 2016; Temizyürek ve Acar, 2014); çocukların davranışlarına etkileri (Adak Özdemir ve Ramazan, 2012; İnan, 2016); motor gelişim kazanımları (Arslan ve Duman, 2018); çocuğun sosyal gelişimindeki rolü (Yağl1, 2013); kahramanları rol model alma (Oruç, Tecim ve Özyürek, 2011) açısından inceleyen çalışmaların da ilgili alan yazında bulunduğu görülmektedir.

Çizgi filmler çocukların yaş ve gelişim dönemi özellikleri dikkate alınarak, çok boyutlu gelişimlerinin desteklenmesi amacı güdülerek ve pedagogların görüş ve önerilerine başvurularak hazırlandığ çocukların yaşlarına, gelişim dönemi özelliklerine uygun seçilmelidirler (Yaşar Ekici, 2015). Ülkemizde yayınlanan çizgi filmlere yönelik araştırmalar incelendiğinde daha çok şiddet unsurlarının incelendiği ve programların değerler eğitimi açısından ele alındığı görülmektedir. İlgili alan yazında çizgi filmlerin okul öncesi dönem gelişim alanları çerçevesinde araştırıldığı bir çalışmaya (Arslan ve Duman, 2018) rastlanmıştır. Bu araştırmada motor gelişim kazanımlarına göre çizgi filmlerin özellikleri belirlenmiştir. Okul öncesi dönem çocuklarına hitap eden çizgi filmlerin 2013 Okul Öncesi Eğitim Programında belirtilen kazanım ve göstergelere göre değerlendirildiği bir araştırmaya rastlanmamıştır. 2013 Okul Öncesi Eğitim Programında "Bilişsel Gelişim" ile ilgili 21 kazanım, "Dil Gelişimi” ile ilgili 12 kazanım, "Sosyal ve Duygusal Gelişim" ile ilgili 17 kazanım, "Motor Gelişim" ile ilgili 5 kazanım ve "Öz Bakım Becerileri” ile ilgili 8 kazanım bulunmaktadır. Çocuklar üzerinde çok yönlü ve önemli etkilerinin bulunduğu kabul edilen çizgi filmlerde daha çok hangi gelişim alanlarına yönelik bilgi ve becerilerin kazandırıldığının belirlenmesi, hangi gelişim alanlarına daha fazla yer verilmesi gerektiğinin ortaya konulması çocukların tüm gelişim alanlarının eşit olarak desteklenmesi açısından önem kazanmaktadır. Bu nedenle bu araştırmada TRT Çocuk Kanalı'nda yer alan ve 3-5 yaş grubu çocuklar için hazırlanmış Kuzucuk, Kare ve Ege ile Gaga adlı çizgi filmler 48 aylık çocukların gelişim özellikleri bakımından değerlendirilmiştir. Çizgi filmlerin değerlendirilmesinde 2013 Okul Öncesi Eğitim Programı kapsamında, evde daha çok zaman geçirmeleri nedeniyle 48 aylık çocuklara kazandırılması hedeflenen bilgi ve beceriler dikkate alınmıştır. Söz konusu çizgi 
filmlerin bilişsel, dil, sosyal ve duygusal, motor ve öz bakım becerileri olmak üzere beş gelişim alanındaki kazanım ve göstergeler göz önünde bulundurularak değerlendirilmesi amaçlanmıştır.

\section{Yöntem}

\section{Araştırma modeli}

$\mathrm{Bu}$ araştırmada; TRT Çocuk Kanalı'nda okul öncesi dönem çocuklarına yönelik olarak yayınlanan çizgi filmlerde yer verilen kazanımların sıklığını tespit etmek amaçlandığından çalışma, nitel araştırma yöntemiyle yürütülmüş ve araştırmada doküman incelemesi tekniğinden yararlanılmıştır. Araştırmaya konu olan olgu ve olgulara ilişkin yazılı materyallerin analizini kapsayan "doküman incelemesi", gerekli durumlarda yazılı kaynakların yanı sıra film, video ya da fotoğraf gibi görsel malzemeleri de kapsamaktadır (Yıldırım ve Şimşek, 2011).

\section{Çalışma grubu}

Araştırmanın çalışma grubunu TRT Çocuk Kanalı'nda yer alan ve 3-5 yaş grubuna yönelik programlardan seçilen; "Kuzucuk", "Kare" ve "Ege ile Gaga" adlı çizgi filmlerin her birinden basit seçkisiz yöntemle belirlenmiş 10'ar bölüm olmak üzere toplamda 30 çizgi film oluşturmaktadır. Çizgi filmlerin her bir bölümünün süreleri yaklaşık olarak "Kuzucuk" için 1215 dakika; "Kare" için 10-12 dakika ve "Ege ile Gaga" için 8 dakikadır. Bölümlerin tamamı sonuna kadar izlenmiştir. Programlar seçilirken, 3-5 yaş grubunda kardeşi veya yakını olan 55 okul öncesi öğretmen adayına, çocukların TRT Çocuk Kanalı'nda yer alan programlardan en çok hangilerini izledikleri sorulmuş ve alınan yanttlar sonucu en çok izlenen; "Kuzucuk, "Kare" ve "Ege ile Gaga" programları seçilmiştir. Çalışma grubuna dahil edilen çizgi filmlerin bölüm isimleri aşağıdaki tabloda listelenmiştir.

Tablo 1.

Çalışma Grubuna Dâhil Edilen Çizgi Filmlerin Bölüm İsimleri Listesi

\begin{tabular}{lll}
\hline Kuzucuk & Ege ile Gaga & Kare \\
\hline Sen de yapabilirsin & Gaga'nın havuzu & Şelale \\
Kaşıntı & Helikopter & Açık-Kapalı \\
Yalıtım & Gündüz Uykusu & Kurabiye Evi \\
Sanatçı Tavşan & Sahildeki İzler & Kayıp Çoraplar \\
Rüzgar Nereden Esiyor & Patatesler ve Soğanlar & Alçak-Yüksek \\
Oyun Merakı & Çıngırak Sesleri & Islak-Kuru \\
Bilginin Değeri & Pırıl Pırıl & Tüylü-Tüysüz \\
Aceleci Kuzucuk & Çiçekler & Farkl1-Benzer \\
Susuz Yaz & Sağım Solum Önüm Arkam & Dev Kovalar \\
Müze & Gaganın Sürprizi & Sergi Açılışı \\
\hline
\end{tabular}

\section{Verilerin toplanması}

Araştırmada "Kuzucuk", "Kare" ve "Ege ile Gaga" adlı çizgi filmlere ait toplam 30 bölüm doküman olarak kabul edilmiştir. İncelenen çizgi film bölümlerinde hangi gelişim alanlarına ne kadar sıklıkla yer verildiğini belirlemek amacıyla "Milli Eğitim Bakanlığ 2013 Okul Öncesi Eğitim Programı"ndan yararlanılmıştır. Çizgi filmler programda yer alan gelişim alanlarına yönelik kazanımlar doğrultusunda incelenmiştir.

Araştırmanın veri toplama aşamasında izlenen adımlar aşağıda sıralanmıştır:

- İki araştırmacı tarafından belirlenen çizgi film bölümleri birbirinden bağımsız izlenmiştir.

- Çizgi filmlerde yer verilen kazanımların doğru ve ayrıntılı bir şekilde değerlendirilebilmesi için bölümler bire bir yazılı metne dönüştürülmüştür.

- Metne dökülen içerikte yer alan gelişim alanlarına yönelik kazanımlar işaretlenmiş ve kodlanmıştır. Örneğin; Kuzucuk çizgi filminin "Sen de yapabilirsin” bölümü incelenirken MEB 2013 Okul Öncesi Eğitim Programındaki beş gelişim alanında bulunan kazanımlara 
yer verilip verilmediği tek tek değerlendirilmiştir. Çizgi film bölümlerinde bulunan kazanımlar; Okul Öncesi Eğitim Programında belirtilen kazanım sırasına ve bu kazanımlara kaç defa yer verildiğine göre kodlanmıştır (Bilişsel Gelişim alanındaki Kazanım 1'e 1 defa yer verilmişse; bilişsel gelişim alanına $\mathrm{K} 1$ = 1 bilgisi girilmiştir).

- Kodlamalar sonucunda iki araştırmacı tarafından ortak gelişim alanlarına ve kazanımlarına ulaşıldığı görülmüştür.

- Verilerin kodlanması sonucu oluşan gelişim alanları ve kazanımların doğruluğu ile ilgili uzman görüşü alınmıştır. 5 alan uzmanına metin haline getirilmiş çizgi film bölümleri ve iki araştırmacı tarafından bu bölümlerde yer verildiği düşünülen gelişim alanları ve kazanımlarının listesi verilmiştir. Alınan görüşler doğrultusunda verilerin son haline ulaşılmıştır.

- Yapılan bu çalışmanın tüm aşamalarında araştırma ve yayın etiğine uyulmuştur.

\section{Verilerin analizi}

Araştırma verilerinin çözümlenmesinde içerik analizi tekniğinden yararlanılmıştır. İçerik analizi, belirli kurallara dayalı kodlamalarla bir metnin bazı sözcüklerinin daha küçük içerik kategorileri ile özetlendiği sistematik, yinelenebilir bir teknik olarak tanımlanmaktadır (Büyüköztürk, Kılıç Çakmak, Akgün, Karadeniz ve Demirel, 2016). İçerik analizi için; çizgi filmlerin izlenmesi sonucu elde edilen verilerden kodlamalar oluşturulmuştur. Oluşturulan kodlamaların güvenirliği için kodlayıcılar arası tutarlılık hesaplanmıştır. Bunun için iki araştırmacı tarafından ortak karara varılmış gelişim alanları ve kazanımlar, çalışmadan bağımsız okul öncesi eğitimi alanında uzman 5 kişinin görüşüne sunulmuştur. Uzmanlar her bir gelişim alanı ve kazanım için "uygun/uygun değil" şeklinde değerlendirme yapmışlardır. Daha sonra kodlayıcılar arası güvenirlik; (Görüş birliği sayıs1 / Görüş birliği sayıs1 + Görüş ayrılığı sayıs1) x 100 formülünden (Miles ve Huberman, 1994) yararlanılarak hesaplanmıştır. Hesaplama sonrası kodlamalardaki uyuşum düzeyi; Kuzucuk çizgi filmi için .75; Kare çizgi filmi için .79; Ege ile Gaga çizgi filmi için .88 olarak belirlenmiştir.

Nitel araştırmalarda iç geçerliği arttırmak için verilerin iki farklı kişi tarafından incelenerek karşılaştırılması önerilmektedir (Büyüköztürk, Kılıç Çakmak, Akgün, Karadeniz ve Demirel, 2016). Bu nedenle geçerliği arttırma adına çizgi filmler iki araştırmacı tarafından bağımsız bir şekilde incelenip elde edilen veriler karşılaştırılmıştır. Ayrıca bulgularda gelişim alanları ve kazanımların yer aldığı bölümlerden doğrudan alıntılar yapılarak yine geçerlik sağlanmaya çalışılmıştır.

\section{Bulgular}

TRT Çocuk Kanalı'nda yayınlanan çizgi filmlerin gelişim alanlarına göre değerlendirilmesi amacıyla yapılan bu araştırmanın bulgularına aşağıda yer verilmiştir:

Tablo 2.

Kuzucuk Çizgi Filminde Yer Verilen Kazanımlara Ait Frekans Değerleri

\begin{tabular}{|c|c|c|c|c|c|c|c|c|}
\hline & \multicolumn{2}{|c|}{ Bilişsel gelişim } & \multicolumn{2}{|c|}{$\begin{array}{c}\text { Sosyal ve duygusal } \\
\text { gelişim }\end{array}$} & \multicolumn{2}{|c|}{ Dil gelişimi } & \multicolumn{2}{|c|}{$\begin{array}{l}\text { Öz bakım } \\
\text { becerileri }\end{array}$} \\
\hline & $\begin{array}{l}\text { Kazanım } \\
\text { Kodu }\end{array}$ & $\mathrm{f}$ & $\begin{array}{l}\text { Kazanım } \\
\text { kodu }\end{array}$ & $\mathrm{f}$ & $\begin{array}{l}\text { Kazanım } \\
\text { kodu }\end{array}$ & $\mathrm{f}$ & $\begin{array}{l}\text { Kazanım } \\
\text { kodu }\end{array}$ & $\mathrm{f}$ \\
\hline \multirow{6}{*}{ Kuzucuk } & $\mathrm{K} 2$ & 8 & K3 & 1 & K5 & 32 & $\mathrm{~K} 1$ & 1 \\
\hline & K3 & 4 & K5 & 12 & K10 & 3 & K3 & 1 \\
\hline & K5 & 5 & K7 & 2 & & & K4 & 1 \\
\hline & K8 & 2 & K9 & 1 & & & K7 & 1 \\
\hline & K17 & 19 & K10 & 2 & & & K8 & 1 \\
\hline & K19 & 12 & K15 & 4 & & & & \\
\hline
\end{tabular}


Kuzucuk çizgi filmi gelişim alanlarına göre kazanımlara yer verme durumu açısından incelendiğinde; Bilişsel Gelişim alanında en çok K17'ye (19) yer verildiği görülmektedir. Daha sonra K19'a 12 kere, K2'ye 8 kere K5'e 5 kere K3'e 4 kere ve K8'e 2 kere yer verilmiştir. Bilişsel Gelişim alanında 21 kazanım bulunmaktadır. Bu çizgi filmde Bilişsel Gelişime ait kazanımlardan "K1, K4, K6, K7, K9, K10, K11, K12, K13, K14, K15, K16, K18, K20 ve K21'e” hiç yer verilmediği bulunmuştur. Sosyal ve Duygusal Gelişim alanında en çok K5'e (12) yer verildiği görülmektedir. K15'e 4 kere K7 ve K10'a 2'şer kere son olarak K3 ve K9'a da 1'er kere yer verilmiştir. Sosyal ve Duygusal Gelişim alanında 17 kazanım bulunmaktadır. Sosyal ve Duygusal Gelişime ait kazanımlardan “K1, K2, K4, K6, K8, K11, K12, K13, K14, K16 ve K17'ye” hiç yer verilmediği görülmüştür. Dil Gelişimi alanında en çok K5'e (32) rastlanmıştır. K10'a da 3 kez yer verildiği görülmektedir. Dil Gelişimi alanında 12 kazanım bulunmaktadır. Dil Gelişimine ait kazanımlardan "K1, K2, K3, K4, K6, K7, K8, K9, K11 ve K12'ye" hiç yer verilmediği görülmüştür. Öz Bakım Becerileri alanında ise toplamda 8 kazanım bulunmaktadır ve Kuzucuk çizgi filminde bu kazanımlardan "K2, K5 ve K6' ya" yer verilmemiş olup diğer kazanımların birer kez kullanıldığı tespit edilmiştir. Rastlanan kazanımlar aşağıda detaylıca açıklanmıştır:

Tablo 2'ye göre Kuzucuk çizgi filminden seçilen bölümlerde bilişsel gelişim alanındaki kazanımlara yer verilme durumu incelendiğinde, K2:"Nesne/durum/olayla ilgili tahminde bulunur" kazanımına 8; K3:“Algıladıklarını hatırlar" kazanımına 4; K5:"Nesne veya varlıkları gözlemler" kazanımına 5; K8:"Nesne veya varlıkların özelliklerini karşılaştırır" kazanımına 2; K17:"Neden-sonuç ilişkisi kurar" kazanımına 19; K19"Problem durumlarına çözüm üretir" kazanımına 12 defa yer verildiği görülmektedir.

- Nesne/durum/olayla ilgili tahminde bulunur: ("Bu ne acele yoksa ibikliye bir şey mi oldu?” Aceleci Kuzucuk Bölümü, Süre 05:32)

- Algıladıklarını hatırlar: ("En son senin evine kova almaya giderken görmüştüm.” Yalıtım Bölümü, Süre 11:23)

- Nesne veya varlıkları gözlemler: (Toprağın incelenmesi sonucunda ince ve yumuşak olduğunun belirtilmesi Yalıtım Bölümü, Süre 8:35).

- Nesne veya varlıkların özelliklerini karşılaştırır: ("Bu kadar ülke gezdim heykelin undan yapılanını görmedim.” Sanatçı Tavşan Bölümü Süre: 11:20)

- Neden-sonuç ilişkisi kurar: ("O halde havanın ısınma ve soğuma zamanını bilirsek ne zaman rüzgar çıkacağını da bilebiliriz.” Rüzgar Nereden Esiyor Bölümü Süre 10:35)

- Problem durumlarına çözüm üretir: ("Bir fikrim var gündüz işlerimizi bitirip akşam rahat rahat oyun oynayabiliriz.” Oyun Merakı Bölümü Süre: 8:15)

Sosyal ve duygusal gelişim alanındaki kazanımlara yer verilme durumu incelendiğinde, K3:"Kendini yaratıc1 yollarla ifade eder" kazanımına 1, K5:"Bir olay veya durumla ilgili olumlu/olumsuz duygularını uygun yollarla gösterir" kazanımına 12; K7:"Bir işi veya görevi başarmak için kendini güdüler" kazanımına 2; K9:"Farklı kültürel özellikleri açıklar” kazanımına 1; K10:"Sorumluluklarını yerine getirir" kazanımına 2; K15: "Kendine güvenir" kazanımına 4 defa yer verildiği bulunmuştur.

- Kendini yaratıc1 yollarla ifade eder: (Ibikli'nin farkl materyallerden (tencere, tava gibi) kendine özgü müzik oluşturması, Aceleci Kuzucuk Bölümü Süre 7:56)

- Bir olay veya durumla ilgili olumlu/olumsuz duygularını uygun yollarla gösterir: (“ $O$ kadar heyecanliyım ki Lak Lak’ı çok özledim." Oyun Merakı Bölümü Süre 1:05)

- Bir işi veya görevi başarmak için kendini güdüler: ("Bahçeyi sulamam lazım sonra çamaşırlar var meyve de toplayacaktım.” Aceleci Kuzucuk Bölümü Süre 1:53).

- Farklı kültürel özellikleri açıklar: ("Hereke halıları dünyaca çok ünlüdür. ” Oyun Merakı Bölümü Süre 2:35) 
- Sorumluluklarını yerine getirir: ("Galiba dün kuzucuğun bahçesine çok zarar verdim. Gidip toparlamam lazım." Sen de Yapabilirsin Bölümü Süre: 8:26)

- Kendine Güvenir: ("Bu altınlart müzeye ben verdim. Kendimle şahsen gurur duyиyorum." Müze Bölümü Süre 12:00)

Dil gelişimi alanındaki kazanımlara yer verilme durumu incelendiğinde, K:5"Dili iletişim amacıyla kullanır” kazanımına 32; K10:“Görsel materyalleri okur” kazanımına 3 defa yer verildiği belirlenmiştir.

- Dili iletişim amacıyla kullanır: Bölümlerin hemen hepsinde "Teşekkürler, Günaydın vb." nezaket sözcüklerinin kullanıldı̆̆ına rastlanmıştır.

- Görsel materyalleri okur: (Radyo kurulumunun resminin olduğu kılavuz kitapçıtan yararlanılmasl, Rüzgar Nereden Esiyor Bölümü Süre: 8:30).

Öz bakım becerileri alanındaki kazanımlara yer verilme durumu incelendiğinde, K1: "Bedeniyle ilgili temizlik kurallarını uygular" kazanımına 1; K3: "Yaşam alanlarında gerekli düzenlemeler yapar" kazanımına 1; K4: "Yeterli ve dengeli beslenir" kazanımına 1; K7: "Kendini tehlikelerden ve kazalardan korur" kazanımına 1; K8: "Sağlığı ile ilgili önlemler alır" kazanımına 1 defa yer verildiği görülmektedir.

- Bedeniyle ilgili temizlik kurallarını uygular: ("Çalışırken çok fazla terledim eve gidip yıkanayım” Kaşıntı Bölümü Süre: 1:20).

- Yaşam alanlarında gerekli düzenlemeler yapar: (Kuzucuk'un yatağını, kişisel eşyalarını toparlamasl, Aceleci Kuzucuk Bölümü Süre 3:15).

- Yeterli ve dengeli beslenir: (Kuzucuğun kahvaltısını yapması, Yalıtım Bölümü Süre 4:16)

- Kendini tehlikelerden ve kazalardan korur: ("Bisiklete patenle binmesi tehlikeli, dikkat etse iyi eder.” Aceleci Kuzucuk Bölümü Süre 5:15).

- Sağlığı ile ilgili önlemler alır: (Kuzucuğun sabah sporunu yapması, Sen de Yapabilirsin Bölümü Süre 4:00).

Tablo 3.

Ege ile Gaga Çizgi Filminde Yer Verilen Kazanımlara Ait Frekans Değerleri

\begin{tabular}{|c|c|c|c|c|c|c|c|c|}
\hline & \multicolumn{2}{|c|}{ Bilişsel gelişim } & \multicolumn{2}{|c|}{$\begin{array}{l}\text { Sosyal ve duygusal } \\
\text { gelişim }\end{array}$} & \multicolumn{2}{|c|}{ Dil gelişimi } & \multicolumn{2}{|c|}{$\begin{array}{l}\text { Öz bakım } \\
\text { becerileri }\end{array}$} \\
\hline & $\begin{array}{l}\text { Kazanım } \\
\text { Kodu }\end{array}$ & $\mathrm{f}$ & Kazanım kodu & $\mathrm{f}$ & $\begin{array}{l}\text { Kazanım } \\
\text { kodu }\end{array}$ & $\mathrm{f}$ & $\begin{array}{l}\text { Kazanım } \\
\text { kodu }\end{array}$ & $\mathrm{f}$ \\
\hline \multirow{13}{*}{$\begin{array}{l}\text { Ege ile } \\
\text { Gaga }\end{array}$} & K1 & 27 & K3 & 2 & K1 & 1 & K7 & 2 \\
\hline & K2 & 24 & K5 & 4 & K5 & 18 & & \\
\hline & K3 & 15 & K7 & 1 & K9 & 2 & & \\
\hline & K4 & 1 & K10 & 1 & & & & \\
\hline & K5 & 3 & K13 & 1 & & & & \\
\hline & K6 & 1 & & & & & & \\
\hline & K7 & 3 & & & & & & \\
\hline & K8 & 15 & & & & & & \\
\hline & K11 & 1 & & & & & & \\
\hline & K13 & 2 & & & & & & \\
\hline & K17 & 15 & & & & & & \\
\hline & K18 & 1 & & & & & & \\
\hline & K19 & 8 & & & & & & \\
\hline
\end{tabular}


Ege ile Gaga çizgi filmi gelişim alanlarına göre kazanımlara yer verme durumu açısından incelendiğinde; Bilişsel Gelişim alanında en çok sırası ile K1 (27) ve K2 (24)'ye yer verildiği görülmektedir. K3, K8 ve K17'ye eşit oranda (15 defa) yer verildiği bulunmuştur. K19'a 8, K5 ve K7'ye 3, K13'e 2, K4, K6, K11 ve K18'e de 1'er defa yer verilmiştir. Bu çizgi filmde Bilişsel Gelişime ait kazanımlardan "K9, K10, K12, K14, K15, K16, K20 ve K21'e” hiç yer verilmediği tespit edilmiştir. Sosyal ve Duygusal Gelişim alanında en çok K5'e (4) yer verildiği görülmektedir. K3'e 2 kere K7, K10 ve K13'e ise eşit şekilde (1kere) yer verilmiştir. Sosyal ve Duygusal Gelişime ait kazanımlardan 'K1, K2, K4, K6, K8, K9, K11, K12, K14, K16 ve K17'ye" hiç yer verilmediği görülmüştür. Dil Gelişimi alanında en çok K5'e (18) rastlanmıştır. K9'a da 2 kez yer verilirken K1'e de 1 kez yer verilmiştir. Dil Gelişimine ait kazanımlardan 'K2, K3, K4, K6, K7, K8, K10, K11 ve K12'ye" hiç yer verilmediği görülmüştür. Öz Bakım Becerileri alanında ise toplamda 8 kazanımdan yalnızca K7'ye 2 kez yer verildiği tespit edilmiştir. Gelişim alanlarına yönelik yer verilen kazanımlar aşağıda detaylıca açıklanmıştır.

Tablo 3'e göre Ege ile Gaga çizgi filminden seçilen bölümlerde bilişsel gelişim alanındaki kazanımlara yer verilme durumu incelendiğinde, K1:"Nesne/durum/olaya dikkatini verir" kazanımına 27; K2:"Nesne/durum/olayla ilgili tahminde bulunur" kazanımına 24; K3:“Algıladıklarını hatırlar", K8:” Nesne veya varlıkların özelliklerini karşılaştırır” ve K17: “ Neden-sonuç ilişkisi kurar" kazanımınlarına 15; K4: "Nesneleri sayar" kazanımına 1; K5"Nesne veya varlıkları gözlemler" kazanımına 3; K6:"Nesne veya varlıkları özelliklerine göre eşleştirir" kazanımına 1; K7:"Nesne veya varlıkları özelliklerine göre gruplar" kazanımına 3; K11:"Nesneleri ölçer” kazanımına 1; K13:"Günlük yaşamda kullanılan sembolleri tanır" kazanımına 2; K18:"Zamanla ilgili kavramları açıklar" kazanımına 1; K19:"Problem durumlarına çözüm üretir" kazanımına 8 defa yer verildiği bulunmuştur.

- Nesne/durum/olaya dikkatini verir: (“Bak Gaga limon yüzüyor.” Gaga’nın Havuzu Bölümü Süre 2:03).

- Nesne/durum/olayla ilgili tahminde bulunur: ("Iki insan sahilde yürüyüşe çıkmış olabilir onların ayak izleri olabilir." Sahildeki izler Bölümü Süre 4:09).

- Algıladıklarını hatırlar: ("Aldığımızda böyle minik parçaları yoktu eminim. O akşam patates yemeği yapmıştı annem." Patatesler ve Soğanlar Bölümü Süre 4:48).

- Nesneleri sayar: (Saz yapraklarının sayılması 1,2,3,4, Yenilenme Bölümü Süre 2:40)

- Nesne veya varlıkları gözlemler: (Batan ve yüzen cisimlerin incelenmesi, Gaga'nın Havuzu Bölümü Süre 5:47).

- Nesne veya varlıkları özelliklerine göre eşleştirir/karşılaştırır: ("Renkleri farklı ama ikisinde de küçük küçük pullar var." Yenilenme Bölümü Süre 5:41).

- Nesne veya varlıkları özelliklerine göre gruplar: ("En iyisi gruplara ayıralım: Güneşi sevenler bu basamağa sevmeyenler bu basamă̆a Çiçekler Bölümü Süre 6:35).

- Günlük yaşamda kullanılan sembolleri tanır: ("Pusulanın renkli ibresi kuzeyi gösteriyor." Să̆ım Solum Önüm Arkam Bölümü Süre 6:08).

- Neden-sonuç ilişkisi kurar: ("Kulakları belki az duyuyordur diye azıcık bağırdım." Gündüz Uykusu Bölümü Süre 4:10).

- Zamanla ilgili kavramları açıklar: (“Yarın söylerim Ege." Gaga'nın Sürprizi Bölümü Süre 1:28).

- Problem durumlarına çözüm üretir: ("Daha önce neden düşünemedim. Evine gitmek zorunda değilsin. Tulumbada yıkanmayı çok seversin. Altında durursun bende senin için su çekerim." Pırıl Pırıl Bölümü 2:33).

Sosyal ve duygusal gelişim alanındaki kazanımlara yer verilme durumu incelendiğinde, K3:"Kendini yaratıc1 yollarla ifade eder" kazanımına 2; K5:"Bir olay veya durumla ilgili olumlu/olumsuz duygularını uygun yollarla gösterir" kazanımına 4; K7:"Bir işi veya görevi başarmak için kendini güdüler" kazanımına 1; K10:"Sorumluluklarını yerine getirir" kazanımına 1; K13:“Estetik değerleri korur” kazanımına 1 defa yer verildiği tespit edilmiştir. 
- Kendini yaratıcı yollarla ifade eder: (Gaga'nın Ege için şiir yazması, Sahildeki İzler Bölümü Süre 1:16).

- Bir olay veya durumla ilgili olumlu/olumsuz duygularını uygun yollarla gösterir: (“Yangın çıkınca pek çok ăgaç yanarmış çok ama çok üzgünüm.” Helikopter Bölümü Süre 6:40).

- Bir işi veya görevi başarmak için kendini güdüler: ("İkimizde çok sabırllydık, araştırmamızı yarıda bırakmadık." Sahildeki İzler Bölümü Süre 6:54).

- Sorumluluklarını yerine getirir: ("Çiçeklerden ben sorumluyum artık." Çiçekler Bölümü Süre 2:48).

- Estetik değerleri korur: ("Fakat daha sonra yanan ağaçların yerine yeni fidanlar diktik." Helikopter Bölümü Süre 7:12).

Dil gelişimi alanındaki kazanımlara yer verilme durumu incelendiğinde, K1:"Sesleri ayırt eder" kazanımına 1; K15:"Dili iletişim amacıyla kullanır” kazanımına 18; K9:"Ses bilgisi farkındalığı gösterir" kazanımına 2 defa yer verildiği görülmektedir.

- Sesleri ayırt eder: ("Sesler bahçenin dışından geliyor." Çıngırak Sesleri Bölümü Süre $2: 22$ ).

- Dili iletişim amacıyla kullanır: Bölümlerin hemen hepsinde Teşekkürler, Günaydın vb. nezaket sözcüklerinin kullanıldiğına rastlanmıştır.

- Ses bilgisi farkındalığı gösterir: ("Sonra sahile gitti tek başına, tam uzanacakken kumlara, çok garip izler çıktı karşısına." Sahildeki İzler Bölümü Süre 1:40).

Öz bakım becerileri alanındaki kazanımlara yer verilme durumu incelendiğinde, K7:"Kendini tehlikelerden ve kazalardan korur" kazanımına 2 defa yer verildiği belirlenmiştir.

- Kendini tehlikelerden ve kazalardan korur: (Ege'nin Gaga'y yeni gördüğü nesne için Dur Gaga dokunma şeklinde uyarmast, Yenilenme Bölümü 2:52).

Tablo 4.

Kare Çizgi Filminde Yer Verilen Kazanımlara Ait Frekans Değerleri

\begin{tabular}{|c|c|c|c|c|c|c|c|c|c|c|}
\hline & \multicolumn{2}{|c|}{$\begin{array}{l}\text { Bilişsel } \\
\text { gelişim }\end{array}$} & \multicolumn{2}{|c|}{$\begin{array}{c}\text { Sosyal ve } \\
\text { duygusal gelişim }\end{array}$} & \multicolumn{2}{|c|}{$\begin{array}{c}\text { Dil } \\
\text { gelişimi }\end{array}$} & \multicolumn{2}{|c|}{$\begin{array}{l}\text { Motor } \\
\text { gelişim }\end{array}$} & \multicolumn{2}{|c|}{$\begin{array}{l}\text { Öz bakim } \\
\text { becerileri }\end{array}$} \\
\hline & $\begin{array}{l}\text { Kazanım } \\
\text { Kodu }\end{array}$ & $\mathrm{f}$ & $\begin{array}{l}\text { Kazanım } \\
\text { kodu }\end{array}$ & f & $\begin{array}{l}\text { Kazanım } \\
\text { kodu }\end{array}$ & $\mathrm{f}$ & $\begin{array}{l}\text { Kazanım } \\
\text { kodu }\end{array}$ & $\mathrm{f}$ & $\begin{array}{l}\text { Kazanım } \\
\text { kodu }\end{array}$ & $\mathrm{f}$ \\
\hline \multirow{12}{*}{ Kare } & K1 & 22 & K1 & 1 & K5 & 37 & K1 & 1 & K3 & 1 \\
\hline & $\mathrm{K} 2$ & 29 & K5 & 11 & K6 & 1 & $\mathrm{~K} 2$ & 1 & & \\
\hline & K3 & 15 & K7 & 1 & K10 & 1 & & & & \\
\hline & K4 & 1 & K10 & 1 & & & & & & \\
\hline & K5 & 10 & K12 & 1 & & & & & & \\
\hline & K6 & 3 & & & & & & & & \\
\hline & K7 & 8 & & & & & & & & \\
\hline & K8 & 31 & & & & & & & & \\
\hline & K11 & 4 & & & & & & & & \\
\hline & K17 & 26 & & & & & & & & \\
\hline & K18 & 3 & & & & & & & & \\
\hline & K19 & 13 & & & & & & & & \\
\hline
\end{tabular}

Kare çizgi filmi gelişim alanlarına göre kazanımlara yer verme durumu açısından incelendiğinde; Bilişsel Gelişim alanında en çok sırası ile K8 (31), K2 (29), K17 (26) ve K1 (22)'e yer verildiği görülmektedir. Daha sonra sirasıyla K3'e 15 kez, K19'a 13 kez K5'e'10 kez K7'ye 
8 kez yer verildiği bulunmuştur. K11'e 4 defa yer verilirken, K18 ve K6'ya 3 defa, K4'e ise yalnızca 1 defa yer verilmiştir. Bu çizgi filmde Bilişsel Gelişime ait kazanımlardan "K9, K10, K12, K13, K14, K15, K16, K20 ve K21'e" hiç yer verilmediği tespit edilmiştir. Sosyal ve Duygusal Gelişim alanında en çok K5'e (11) yer verildiği görülmektedir. K1, K7, K10 ve K12'ye ise 1'er kez rastlanmıştır. Sosyal ve Duygusal Gelişime ait kazanımlardan "K2, K3, K4, K5, K6, K8, K9, K11, K13, K14, K15, K16 ve K17'ye” hiç yer verilmediği görülmüştür. Dil Gelişimi alanında en çok K5'e (37) rastlanmıştır. K6 ve K11'e ise 1 kez yer verilmiştir. Dil Gelişimine ait kazanımlardan "K1, K2, K3, K4, K7, K8, K9, K10 ve K12'ye” hiç yer verilmediği görülmüştür. Motor Gelişim alanında ise toplamda 5 kazanımdan K1 ve K2'ye 1 kez rastlanmıştır. Öz Bakım Becerileri alanında ise toplamda 8 kazanımdan yalnızca K3'e 1 kere yer verildiği tespit edilmiştir. Kazanımlara yönelik detaylı açıklama aşağıda yer almaktadır.

Tablo 4'e göre Kare çizgi filminden seçilen bölümlerde bilişsel gelişim alanındaki kazanımlara yer verilme durumu incelendiğinde, K1:"Nesne/durum/olaya dikkatini verir" kazanımına 22; K2:"Nesne/durum/olayla ilgili tahminde bulunur" kazanımına 29; K3:"Algıladıklarını hatırlar" kazanımına 15; K4:"Nesneleri sayar" kazanımına 1; K5:"Nesne veya varlıkları gözlemler" kazanımına 10; K6:"Nesne veya varlıkları özelliklerine göre eşleştirir" kazanımına 3; K7:"Nesne veya varlıkları özelliklerine göre gruplar" kazanımına 8; K8:"Nesne veya varlıkların özelliklerini karşılaştırır" kazanımına 31; K11:"Nesneleri ölçer” kazanımına 4; K17:"Neden-sonuç ilişkisi kurar" kazanımına 26; K18:"Zamanla ilgili kavramları açıklar" kazanımına 3; K19:"Problem durumlarına çözüm üretir" kazanımına 13 defa yer verildiği bulunmuştur.

- Nesne/durum/olaya dikkatini verir: ("Bakın herkes uyurken ambulanslar iş başında." Sergi Açılışı Bölümü Süre 1:11).

- Nesne/durum/olayla ilgili tahminde bulunur: ("Bay badana biri siz moladayken merdivenleri değiştirmiş olabilir.” Alçak-Yüksek Bölümü Süre 7:26).

- Algıladıklarını hatırlar: ("Ben bir şelale görmüşü̈m. Sular tıpk kaydıraktaki suyun havuza aktlğı gibi aklyor ve ne kadar güzel bir ses çıkarlyordu." Şelale Bölümü Süre 00:42).

- Nesneleri sayar: (“ 1,2, ...5 bu tüyler tam 5cm uzunluğunda.” Tüylü-Tüysüz Bölümü Süre 5:57).

- Nesne veya varlıkları gözlemler: ("Düğmelerin büyüklükleri farkll.” Dev Kovalar Bölümü Süre 6:08).

- Nesne veya varlıkları özelliklerine göre eşleştirir: ("Bu çorap tekini alıp diğerleriyle karşılaştıracağım. Böylece onun eşini bulacağım.” Kayıp Çoraplar Bölümü Süre 7:06).

- Nesne veya varlıkları özelliklerine göre gruplar: ("Islak-Kuru gruplaması şarkı ile anlatılarak yapılmış.” Islak-Kuru Bölümü Süre 9:00).

- Nesne veya varlıkların özelliklerini karşılaştırır: ("Bu yumurta ve bu yumurtanın üzerinde kahverengi lekeler var. Üstelik yüzeyleri pürüzlü. Çatlayan yumurta krem renginde ve tamamen pürüzsüz." Farkl-Benzer Bölümü Süre 5:38).

- Nesneleri ölçer: (“Bu yumurta 15cm genişliğinde.” Farkll-Benzer Bölümü Süre 6:01).

- Neden-sonuç ilişkisi kurar: ("Buradaki arazi düz değil eğimli o yüzden hızlı gidiyorsunuz." Şelale Bölümü Süre 5:51).

- Zamanla ilgili kavramları açılar: ("Bugün bayan süzgeç kurabiye evini açıyor." Kurabiye Evi Bölümü Süre 1:28).

- Problem durumlarına çözüm üretir: ("Benim taburem yüksek buna otur Enda.” AlçakYüksek Bölümü Süre 00:53).

Sosyal ve duygusal gelişim alanındaki kazanımlara yer verilme durumu incelendiğinde, K1:"Kendisine ait özellikleri tanıtır" kazanımına 1; K5:"Bir olay veya durumla ilgili olumlu/olumsuz duygularını uygun yollarla gösterir" kazanımına 11; K7:"Bir işi veya görevi 
başarmak için kendini güdüler" kazanımına 1; K10:"Sorumluluklarını yerine getirir" kazanımına 1; K12:"Değişik ortamlardaki kurallara uyar" kazanımına 1 defa yer verildiği görülmektedir.

- Kendisine ait özellikleri tanıtır: (“Kare takımı ben Bay Başlak iyi ki geldiniz.” Şelale Bölümü Süre 3:56).

- Bir olay veya durumla ilgili olumlu/olumsuz duygularını uygun yollarla gösterir: ("Kare takımı sizi gördügüme ne kadar sevindim anlatamam." Islak-Kuru Bölümü Süre 7:50).

- Bir işi veya görevi başarmak için kendini güdüler/ Sorumluluklarını yerine getirir: ("Ben boyamaya yardım ederim. Hemen bitiririz Bay Badana.” Alçak-Yüksek Bölümü Süre 8:38).

- Değişik ortamlardaki kurallara uyar: ("Şehir sakinlerinin uykusunu kaçırdığım için özür dilerim." Açık-Kapalı Bölümü Süre 3:11).

Dil gelişimi alanındaki kazanımlara yer verilme durumu incelendiğinde, K5:"Dili iletişim amacıyla kullanır" kazanımına 37; K6:"Sözcük dağarcığını geliştirir” kazanımına 1; K10:“Görsel materyalleri okur" kazanımına 1 defa yer verildiği belirlenmiştir.

- Dili iletişim amacıyla kullanır: Bölümlerin hemen hepsinde "Teşekkürler, Günaydın vb." nezaket sözcüklerinin kullanıldığına rastlanmıştır.

- Sözcük dağarcığını geliştirir: ("Kapı kapalı işte şimdi açık." Zıt anlamlı sözcükler tekrarlanmış. Açı-Kapalı Bölümü Süre 10:03).

- Görsel materyalleri okur: ("Bu tabeladaki yön işaretinde 2 şekil var.” Şelale Bölümü Süre 7:37).

Motor gelişim alanındaki kazanımlara yer verilme durumu incelendiğinde, K1:"Yer değiştirme hareketleri yapar" kazanımına 1; K2:"Denge hareketleri yapar" kazanımına 1 defa yer verildiği görülmektedir.

- Yer değiştirme hareketleri yapar/Denge hareketleri yapar (Sek sek oyununun oynanmast, Kayıp Çoraplar Bölümü Süre 1:09).

Öz bakım becerileri alanındaki kazanımlara yer verilme durumu incelendiğinde, K3:"Yaşam alanlarında gerekli düzenlemeler yapar" kazanımına 1 defa yer verildiği görülmektedir.

- Yaşam alanlarında gerekli düzenlemeler yapar: ("Merak etmeyin hemen mavi tozları temizleyeceğim.” Açık-Kapalı Bölümü Süre 10:00).

\section{Tartışma, Sonuç ve Öneriler}

Bu araştırmada Kuzucuk, Ege ile Gaga ve Kare çizgi filmlerinden seçilen bölümlerin 2013 MEB Okul Öncesi Eğitimi Programındaki gelişim alanlarında yer alan kazanımlara göre incelenmesi amaçlanmıştır.

Kuzucuk çizgi filminde bilişsel gelişim alanında yer alan kazanımlara yönelik durum veya olaylara sıkça yer verildiği sonucuna ulaşılmıştır. Bu kazanımlar içerisinden en fazla nedensonuç ilişkisi kurma ve problemlere çözüm üretme kazanımları üzerinde durulduğu belirlenmiştir. Sosyal duygusal gelişim alanında ise daha çok duygularını uygun yollarla gösterme kazanımına yönelik durumlara yer verilmiştir. Dil gelişimi alanında dili iletişim amacıyla kullanma kazanımı çizgi filmde ağırlıklı olarak yer almıştır. Kuzucuk çizgi filminde motor gelişim alanında yönelik herhangi bir kazanım bulunmamaktadır. Öz bakım becerileri alanındaki kazanımlardan toplam üç kazanıma yönelik durum veya olay olduğu görülmüştür.

Ege ile Gaga çizgi filminde bilişsel gelişim alanına yönelik kazanımlar üzerinde sıklıkla durulduğu belirlenmiştir. 2013 MEB Okul Öncesi Eğitim Programının bilişsel gelişim alanı 
bölümünde sunulmuş olan kazanımların birçoğuna Ege ile Gaga çizgi filminde yer verildiği belirlenmiştir. Çizgi filmde bu kazanımlar içerisinden en çok dikkatini verme, tahminde bulunma, algıladıklarını hatırlama, neden-sonuç ilişkisi kurma ve karşılaştırma yapma kazanımları üzerinde durulmuştur. Sosyal duygusal gelişim alanında da yine Kuzucuk çizgi filmindeki benzer olarak daha çok duygularını uygun yollarla gösterme kazanımına yer verilirken dil gelişimi alanında da yine dili iletişim amacıyla kullanma kazanımı en çok yer verilen kazanım olarak belirlenmiştir. Ege ile Gaga çizgi filminde motor gelişim alanına yönelik herhangi bir kazanıma yer verilmemiştir. Öz bakım becerileri alanından ise yalnızca bir kazanımın araştırmaya dahil olan çizgi film bölümlerinde yer aldığı sonucuna ulaşılmıştır.

Kare çizgi filminde de diğer çizgi filmlerdeki gibi bilişsel gelişim alanına yönelik kazanımlara çoğunlukla yer verilmiştir. Karşılaştırma yapma, neden-sonuç ilişsisi kurma, dikkatini verme, tahminde bulunma, algıladıklarını hatırlama, problem durumlarına çözüm üretme, nesne veya varlıkları gözlemleme kazanımları Kare çizgi filminde en çok üzerinde durulan kazanımlar olmuştur. Sosyal duygusal gelişim alanında ise yine birbirinden farklı kazanımlara yer verilmiş olup en çok duygularını uygun yollarla gösterme kazanımı yer almıştır. Dil gelişimi alanında diğer iki çizgi filmlerde olduğu gibi en fazla dili iletişim amacıyla kullanma kazanımı ön plana çıkmaktadır. Kare çizgi filminde Kuzucuk ve Ege ile Gaga çizgi filmlerinden farklı olarak motor gelişim alanından iki kazanıma yer verilmiştir. Bu kazanımlar yer değiştirme hareketleri yapma ve denge hareketleri yapma kazanımlarıdır. Öz bakım becerileri alanına ait sonuçlar incelendiğinde ise Kare çizgi filminde bu alana yönelik olarak yalnızca yaşam alanlarında gerekli düzenlemeler yapma kazanımına yer verildiği görülmüştür.

Araştırmada Kuzucuk, Ege ile Gaga ve Kare çizgi filmlerinden seçilen bölümlerin tümünün 2013 MEB Okul Öncesi Eğitim Programındaki kazanımlara göre incelenmesi sonucu elde edilen sonuçlara bakıldığında, üç çizgi filmde bilişsel gelişim alanına ve sosyal duygusal gelişim alanına yönelik kazanımlara ağırlık verildiği görülmüştür. 2013 MEB Okul Öncesi Eğitim Programında yer alan gelişim alanları ve bu alanlara ait kazanımlar incelendiğinde; bilişsel gelişim alanında 21, sosyal ve duygusal gelişim alanında 17, dil gelişim alanında 12, öz bakım becerileri alanında 8 ve motor gelişim alanında 5 kazanımın olduğu görülmektedir. Dolayısıyla bu araştırmada ele alınan çizgi filmlerde de bilişsel ve sosyal duygusal gelişim alanına yönelik kazanımlara daha fazla yer verilmesi olası bir durum olarak karşılanabilir. İncelenen çizgi filmlerde bilişsel gelişim alanında en fazla tahminde bulunma, neden-sonuç ilişkisi kurma, dikkatini verme, karşılaştırma yapma, problem durumlarına çözüm üretme kazanımlarına; sosyal duygusal gelişim alanında ise en çok duygularını uygun yollarla gösterme, kendini güdüleme, sorumluluklarını yerine getirme, kendine güvenme kazanımlarına yer verildiği belirlenmiştir. Üç çizgi filmde de dil gelişimi alanı ile ilgili olarak dili iletişim amacıyla kullanma kazanımına yer verilmiştir. Film kahramanları arasındaki diyaloglarda özellikle nezaket sözcükleri sıklıkla kullanılmaktadır. Bunun dışındaki kazanımların fazla yer almadığı görülmüştür. Üç çizgi filmde de motor gelişim alanına ait kazanımlar göreceli olarak daha az yer almıştır. Kuzucuk ve Ege ile Gaga'nın incelenen bölümlerinde motor gelişim alanındaki kazanımlardan herhangi birine rastlanmamıştır. Motor gelişim alanına yalnızca Kare çizgi filminde yer verilmiş ancak bu çizgi filmde de söz konusu alanla ilgili yalnızca iki kazanımın bulunduğu sonucuna ulaşılmıştır. Üç çizgi filmde de öz bakım becerilerinde yer alan kazanımların bazılarına yer verilmiştir.

Sonuç olarak; araştırma dahilindeki çizgi filmlerde bilişsel gelişim alanındaki ve sosyal duygusal gelişim alanındaki kazanımlara yönelik durum ve olaylara ağırlıklı olarak yer verildiği belirlenmiştir. Yağlı (2013) çalışmasında çizgi filmlerin çocukların bilişsel becerilerini geliştirdiğini, onları düşünme ve karşılaştırma yapmaya yönelttiğini belirtmiştir. Singer ve Singer (1998) tarafindan farklı kültür ve irklardan olan okul öncesi çocuklarla gerçekleştirilen bir çalışmada "Barney ve Arkadaşları", "Susam Sokağı" ve "Mister Rogers' Neighborhood" gibi eğitici programların, bu yaş grubundaki çocukların bilişsel, sosyal ve dil gelişimine olumlu etkisi olduğu görülmüştür. $\mathrm{Bu}$ etkiler içinde sayı sayma, konuşma becerilerinde, şekil ve renk bilgilerinde artış, saygı, sevgi, paylaşma, arkadaşlık gibi konularda olumlu duygular hissetme ve tutumlar gösterme mevcuttur (akt. Çamlıbel İrkin, 2012). Yine bazı televizyon programlarının çocukta istenen sosyal davranışı geliştirme, paylaşma, yardımlaşma duygusunu aşılama, zihinsel 
gelişim sürecini hızlandırma, karşılıklı duygu paylaşımı gibi çocuğun gelişimine katkıları bulunmaktadır (Önder ve Balaban Dağal, 2005b). Araştırma sonucunda da izlenilen çizgi filmlerde bilişsel gelişim ve sosyal gelişim alanına yönelik kazanımların ağırlıkta olduğu görülmektedir. Araştırma kapsamında incelenen çizgi filmlerde genellikle benzer kazanımlara yer verildiği belirlenmiştir. Buradan hareketle 2013 MEB Okul Öncesi Eğitim Programında belirtilen bilişsel ve sosyal duygusal gelişim alanlarına ait farklı kazanımlara da söz konusu çizgi film bölümlerinde yer verilmesi gerektiği düşünülebilir.

Dil gelişim alanında çoğunlukla nezaket sözcükleri kullanma (dili iletişim amacıyla kullanma) kazanımının yer aldığı görülmüştür. Yapılan araştırmalarda televizyonun ve çizgi filmlerin çocukların dil gelişiminde olumlu etkisinden söz edilmektedir (Kara, 2015; Kurt, 2014; Palmer, 2011; Serhatlığlu, 2006; Ünal ve Durualp, 2012). Araştırmada da benzer şekilde dil gelişim alanında MEB 2013 Okul Öncesi Eğitimi Programı'nda bulunan 12 kazanımdan 5'ine yer verilmiştir. Fakat bu kazanımların tekrarlanması açısından sadece birine odaklanılması, eksiklik olarak görülmektedir; söz konusu gelişim alanıyla ilgili diğer kazanımlara da önem verilmesi gerekmektedir.

Öz bakım becerileri ve motor gelişim alanında da göz ardı edilmeyecek bir eksiklik olduğu söylenebilir. Çizgi filmlerde yer alan kazanımlara yönelik çeşitliliğin ve tekrarın sağlanması, bu iki gelişim alanı için ihtiyaç olarak görülmektedir. Çocukların model alma yoluyla ögrendiklerinden yola çıkılarak öz bakım becerilerine yönelik kazanımların çizgi filmlerde yer almasının etkili olabileceği düşünülmektedir.

Araştırma sonucunda motor gelişim alanıyla ilgili olarak söz konusu çizgi filmlerde çocuklara olumlu tutum-davranış kazandıracak durum veya olaylara neredeyse hiç yer verilmemiş̧ir. Araştırma sonucuna benzer olarak Arslan ve Durmuş (2018) araştırmalarında Okul Öncesi Eğitim Programı'nda yer alan motor gelişim kazanımlarını; Pepee, Kuzucuk ve Elif' in Düşleri isimli çizgi filmlerde incelemişlerdir. 230 çizgi filmin izlendiği araştırma sonucunda; motor gelişim alanının en fazla yer aldığı çizgi film Pepee olmuştur; fakat 102 bölüm izlenen Pepee çizgi filminde motor gelişim kazanımı frekansı 23 olarak bulunmuştur. Arslan ve Durmuş'un (2018) inceledikleri çizgi filmlerde yer alan motor gelişim alanına yönelik kazanımların yeterli düzeyde olmadığı görülmüştür. Bu açıdan söz konusu araştırma sonuçları ile bu araştırma sonuçlarının örtüştügü söylenebilir. Yine Yılmaz ve Çelik (2018) araştırmalarında çizgi filmlerde spor unsurlarını incelemiş ve çizgi filmlerde spor konusunun işlenmesinin küçük yaşlarda spora karşı olumlu bir bakış açısı kazanılmasında etkili olabileceği görüşünde bulunmuşlardır. Yapılan araştırmalar da çizgi filmlerde motor gelişim alanındaki kazanımlara daha fazla yer verilmesi gerektiğini göstermektedir.

Gelişimin bir bütün olduğu ve tüm gelişim alanlarının birbirini desteklediği göz önünde bulundurulduğunda, çizgi filmler aracılığıyla çocuklara kazandırılması hedeflenen davranışlarda belirli bir gelişim alanına odaklanılmaması gerektiği söylenebilir. Bunun yerine birbirinden farklı becerilerin birbirine yakın seviyelerde desteklenmesinin çocuğun gelişimine en yüksek düzeyde katk1 sağlayacağı düşünülebilir.

Araştırma sonuçlarından hareketle; okul öncesi dönem çocuklarına yönelik yayımlanan ve bu araştırmada ele alınan çizgi filmlerin içeriğinin etkili bir şekilde düzenlenmesinde farklı kazanım ve göstergelerin ele alınması önerilmektedir. Bu araştırmada sınırlı sayıda çizgi film değerlendirildiği için çizgi film sayısı arttırılarak daha kapsamlı bir incelemenin yapılması araştırmacılara önerilmektedir. Her bir çizgi film bölümü kendi içinde değerlendirilerek daha detaylı ve çok yönlü bir biçimde incelenebilir. Ayrıca bu araştırmada sınırlı sayıda çizgi film bölümü ele alındığından karakter sayısı, karakter özellikleri, bölüm uzunluğu, çizgi filmin konusu gibi faktörler üzerinde durulmamıştır. Söz konusu durum araştırmanın sınırlılığı olarak kabul edilebilir. İncelenen çizgi filmlerde farklı kazanımlara yer verilip verilmemesi durumu, konu, karakter, bölüm uzunluğu gibi etmenlerden etkilenebilir. Bu nedenle farklı araştırmalar planlanırken bu etmenlerin de göz önünde bulundurulması araştırmacılara önerilmektedir. 
Katkısı Olanlar: Araştırmanın ilgili bölümlerindeki Türkçe metinlerin İngilizce diline çevrilmesi aşamasında desteğini esirgemeyen, Roehampton Üniversitesi doktora öğrencisi Nizamettin Akbulut'a emekleri için teşekkür ederiz.

\section{Kaynaklar}

Adak Özdemir, A. ve Ramazan, O. (2012). Çizgi filmlerin çocukların davranışları üzerindeki etkisinin anne görüşlerine göre incelenmesi. M.Ü. Atatürk Eğitim Fakültesi Eğitim Bilimleri Dergisi, (35), 157-173.

Akıncı, A. ve Güven, G. (2014). Okul öncesi döneme yönelik çizgi filmlerde yer alan değerlere ait sözel ifadelerin sunumu: TRT çocuk kanalı örneği. Uluslararası Avrasya Sosyal Bilimler Dergisi, 5(16), 429-445.

Arslan, A. ve Duman, E. Z. (2018). Okul Öncesi Eğitim Programında yer alan motor gelişim kazanımlarının çizgi filmlerdeki sunumu. Sosyal Araştırmalar ve Davranış Bilimleri Dergisi, 4(6), 320-344.

Avc1, M. (2010). Çocuk suçluluğunda medyanın rolü. Erzincan Eğitim Fakültesi Dergisi, 12(1), 125-145.

Aydın, B. (2018). Türkiye'de çocuk televizyon kanallarındaki çizgi filmlerin çocukluğa etkisi üzerine bir içerik analizi (Yayımlanmamış yüksek lisans tezi). Balıkesir Üniversitesi, Balıkesir.

Balaban, A. (2002). Televizyon çocuk programlarının kalite kriterlerine ilişkin olarak okul öncesi kurumlarına devam eden çocukların anne-babalarının görüşleri (Yayımlanmamış yüksek lisans tezi). Marmara Üniversitesi, İstanbul.

Büyükbaykal, G. N. (2007). Televizyonun çocuklar üzerindeki etkileri. İstanbul Üniversitesi Illetişim Fakültesi Dergisi, 28, 31-44.

Büyüköztürk, Ş., Kılıç Çakmak, E., Akgün, Ö. E., Karadeniz, Ş. ve Demirel, F. (2016). Bilimsel araştırma yöntemleri. Ankara: Pegem Akademi.

Cesur, S. ve Paker, O. (2007). Televizyon ve çocuk: Çocukların TV programlarına ilişkin tercihleri. Elektronik Sosyal Bilimler Dergisi, 6(19), 106-125.

Cebeci, S. ve Demir, R. (2018). 4-6 yaş grubu çocukların çizgi filmlerden etkilenme durumları. The Journal of Academic Social Science Studies, (67), 291-306.

Coşkun, E. ve Köroğlu, M. (2016). Pepee ve Caillou çizgi filmlerinde kavram öğretimi. Milli Ĕgitim, (210), 601-619.

Çamlıbel İrkin, A. (2012). Çocukların gelişim süreci ve televizyonun etkileri (Yayımlanmamış uzmanlık tezi). T.C. Radyo ve Televizyon Üst Kurulu, Ankara.

Demiral, U., Yamaner, E. ve Süklüm, N. (2016). Çizgi filmlerde verilen eğitimsel mesajlar; TRT çocuk kanalı örneği. Uluslararası Sosyal Araştırmalar Dergisi, 9(45), 536544.

Gülşen, S. (2006). Okul öncesi çocuklarının televizyon izleme alışkanlıklarının bazı değişkenlere göre incelenmesi (Yayımlanmamış yüksek lisans tezi). Fırat Üniversitesi, Elazı̆g.

Günaydın, B. (2011). Çocuklara yönelik programlarda toplumsal cinsiyet rollerinin sunumu: TRT Çocuk ve Yumurcak TV (Yayımlanmamış uzmanlık tezi). RTÜK, Ankara.

Hamarat, D., Işıtan, S., Özcan, A. ve Karaşahin, H. (2015). Okul öncesi dönem çocuklarının izledikleri çizgi filmler üzerine bir inceleme: Caillou ve Sünger Bob örneği üzerine bir model önerisi. Balıkesir Üniversitesi Sosyal Bilimler Enstitüsü Dergisi, 18(33), 75-91.

İnan, T. (2016). Çizgi filmlerin okulöncesi çocuklarının problem davranışlarına etkisi. Uluslararası Sosyal Araştırmalar Dergisi, 9(43), 1432-1445.

İnanl1, M. S. (2008). Televizyondaki çocuk programlarının beş-altı yaş çocukları için sözel şiddet ve antisosyal sözcükler içerme durumunun incelenmesi (Yayımlanmamış yüksek lisans tezi). Gazi Üniversitesi, Ankara.

Kara, İ. (2015). TV programlarının okulöncesi öğrencilerinin dil ve kavram gelişimine katkılarının öğretmen görüş̧leri açısından incelenmesi (Siirt ili örneği) (Yayımlanmamış yüksek lisans tezi). Selçuk Üniversitesi, Konya. 
Karakuş, N. (2015). Okul öncesi döneme hitap eden tema içerikli çizgi filmlerin değerler eğitimine katkısı yönünden değerlendirilmesi (Niloya örneği). Değerler Eğitimi Dergisi, 12(30), 251-277.

Kurt, E. (2014). TRT çocuk kanalının 4-6 yaş grubu öğrencilerinin dil gelişimine etkisi hakkında ögrenci, ögretmen ve veli görüşleri (Yayımlanmamış yüksek lisans tezi). Karadeniz Teknik Üniversitesi, Trabzon.

MEB (2013). Milli Eğitim Bakanlı̆̆̀ Temel Eğitim Genel Müdürlüğü Okul Öncesi Eğitim Programi.

Miles, M. B. ve Huberman, A. M. (1994). An expanded sourcebook: Qualitative data analysis (Second edition). Thousand Oaks, CA: Sage Publications, Inc.

Oruç, C., Tecim, E. ve Özyürek, H. (2011). Okul öncesi dönem çocuğunun kişilik gelişiminde rol modellik ve çizgi filmler. EKEV Akademi Dergisi, (48), 303-319.

Önder, A. ve Balaban Dağal, A. (2005a). Televizyon ve okul öncesi dönem çocuğu. (içinde $O k u l$ Öncesi Eğitimde Güncel Sorunlar) (Edt. A. Oktay ve Ö. Polat Unutkan). (249-264). İstanbul: Morpa Yayınları.

Önder, A. ve Balaban Dağal, A. (2005b). Okul öncesi çocukların annelerinin "Benimle Oynar mısın?" çocuk programını kalite kriterlerine göre değerlendirmesi. II. Uluslararası Çocuk ve İletişim Kongresi, s.171-184.

Özkan, B. ve Yılmaz, Ö. (2016). Okul öncesi dönem 5-6 yaş çocuklarının televizyon izleme alışkanlıkları ve televizyon programları hakkında anne görüşleri. Uluslararası Eğitim Bilimleri Dergisi / The Journal of International Education Science, 7, 118-126.

Öztürk, H. E. (2002). Çocuk ve televizyon. İstanbul: Beyan Yayınları.

Özyürek, A., Kaya, B., Yeşil, Z. ve Karadaş, İ. (2018). Keloğlan Masalları çizgi filminin değerler açısından incelenmesi. Karabük Üniversitesi Sosyal Bilimler Enstitüsü Dergisi, (4), 1-11.

Palmer, S. (2011). Zehirlenen çocukluk-modern dünyanın çocuklar üzerindeki zararlı etkileri. Ö. Ç. Aksoy (Çev.). İstanbul: İletişim Yayınları.

Pekşen Akça, R. ve Baran, G. (2018). Çizgi filmlerin Türk kültürüne ait özellikler açısından incelenmesi: Pepee örneği. Yalova Sosyal Bilimler Dergisi, 8(17), 215-224.

Persegani, C., Russo, P., Carucci, C., Papeschi, L. L., Trimarchi, M. ve Nicolini, M. (2002). Television viewing and personality structure in children. Individual Differences, 32, 977990.

Serhatlığlu, B. (2006). Televizyon programlarının okul öncesi eğitim kurumuna devam eden 5 6 yaş grubu çocuklarının zihin ve dil gelişimini etkileme biçimlerine yönelik öğretmen ve veli görüşlerinin belirlenmesi (Elazlğ ili örneği) (Yayımlanmamış yüksek lisans tezi). Firat Üniversitesi, Elazı ̆.

Straker, L., Pollock, C., Zubrick, S. R., ve Kurinczuk, J. J. (2006). The association between information and communication technology exposure and physical activity, musculoskeletal and visual symptoms and socio-economic status in 5-year-olds. Child: Care, Health and Development, 32, 343-351.

Şirin, M. R. (1999). Televizyon, çocuk ve aile. İstanbul: İz Yayıncılık.

Temizyürek, F. ve Acar, Ü. (2014). Çizgi filmlerdeki subliminal mesajların çocuklar üzerindeki etkisi. Cumhuriyet International Journal of Education-CIJE, 3(3), 25-39.

TÜİK (2013). 6-15 yaş grubu çocuklarda bilişim teknolojileri kullanımı ve medya. (Erişim tarihi: 18.07.2019), Erişim adres: http://www.tuik.gov.tr/PreHaberBultenleri.do?id=15866.

Ünal, N. ve Durualp, E. (2012). Televizyonun okul öncesi çocuklar üzerindeki etkisi. Çankırı Karatekin Üniversitesi Sosyal Bilimler Sosyal Bilimler Enstitüsü Dergisi, 3(2), 93-104.

Woolfolk, A. E. (1998). Educational psychology, U.S.A: Allyn and Bacon.

Yağlı, A. (2013). Çocuğun eğitiminde ve sosyal gelişiminde çizgi filmlerin rolü: Caillou ve Pepee örneği. International Prediodical For The Language, Literatuare and History of Turkish, $8(10), 707-719$.

Yapıcı, Ş. (2006). Bir eğitim aracı olarak televizyon ve etkileri. Bilim, Eğitim ve Düşünce Dergisi, $6(2), 1-15$. 
Yaşar Ekici, F. (2015). Çizgi filmlerin çocuklar üzerindeki etkilerine ilişkin çok boyutlu bir değerlendirme. Türk \& Islam Dünyası Sosyal Araştırmalar Dergisi, (5), 70-84.

Yıldırım, A. ve Şimşek, H. (2011). Sosyal bilimlerde nitel araştırma yöntemleri. Ankara: Seçkin Yayıncilik.

Yılmaz, A. ve Çelik, A. (2018). Çizgi filmlerdeki spor unsurlarının incelenmesi: Niloya ve Kuzucuk örnekleri. CBÜ Beden Eğitimi ve Spor Bilimleri Dergisi, 13(2), 296-309.

\section{Extended Abstract}

\section{Introduction}

Preschool period, which includes the first six years of life; It is a period in which brain development and synaptic connections are very fast and intense (MEB, 2013). Children interact with the environment in which they live and with the social variables within environmental factors (MEB, 2013; Woolfolk, 1998). Nowadays, mass communication tools arise prominence among social variables (Inanl, 2008). Television, which is one of the mass media, is important in terms of reaching out to large masses easily (Ünal \& Durualp, 2012). The level of impacts of television on the children depends on their ages, developments, familial and environmental factors, and the contents of the programmes which are watched by these children (Büyükbaykal, 2007). In the related literature, it was determined that children's favourite programme type was cartoons until the age of 10 years (Cesur \& Paker, 2007). Television programmes have many positive and negative effects on children (Kurt, 2014). When the programs are prepared in an educational, controlled and correct manner; it provides positive effects on children such as teaching concepts, teaching national and spiritual values, preparing for school, language development, learning new words (Günaydın, 2011).

When the researches about the cartoons published in our country are examined, it is seen that the programs are mostly handled in terms of values education and violence elements. No research has been found in which cartoons for preschool children are evaluated according to the learning outcomes and indicators specified in the 2013 Preschool Education Programmes. In cartoons, which are considered to have multifaceted and important effects on children, it is important to determine which development areas are gained more knowledge and skills, to reveal which development areas should be given more space, and to support all development areas of children equally. For this reason, in this study, the cartoons which are prepared for children aged 3-5 years in TRT Children's Channel; "Kuzucuk, Kare and Ege ve Gaga" cartoons were evaluated according to the learning outcomes and indicators of 2013 Preschool Education Programme. It is aimed to examine the mentioned cartoons by taking into consideration the learning outcomes and indicators in five development areas: cognitive, language, social and emotional, motor and selfcare skills.

\section{Method}

This research was conducted with qualitative research method and document analysis technique was used in the research. The study group of research has been determined from the cartoons of TRT Children's Channel, which are aimed at children who are between 3-5 age years olds. These cartoons names are "Kuzucuk, Kare and Ege ile Gaga". A total of 30 sections, 10 of which were from each cartoon, were selected. The mentioned parts of cartoons were determined by simple random method. When the programmes were selected, 55 preschool teacher candidates, who are siblings or relatives of 3-5 years children, were asked which of the programs on the TRT Children's Channel most of the children watched. According to the answers received, the mostwatched programs were determined as "Kuzucuk, Kare and Ege ile Gaga". Thus, these cartoons were selected for the research. Content analysis technique was used in the analysis of the research data. For reliability, 5 experts in the field created independent coding and consistency between the coders was calculated. The consistency level in coding for "Kuzucuk" as .75; for "Kare" as .79 ; for "Ege ile Gaga" as .88 was determined. 


\section{Result and Discussion}

As a result of the research, in the field of cognitive development, it was determined that making the most guesswork, establishing a cause-effect relationship, paying attention, making comparisons, finding solutions to problem situations. In the field of social-emotional development, it was determined that the most important aspects were showing the emotions in appropriate ways, self-motivation, the fulfilment of responsibilities, self-confidence learning outcomes. In all three cartoons, gaining the use of language for communication in the field of language development was mentioned. In the dialogues between the characters, especially the words of kindness are frequently used. It has seen that, except for this outcome, other outcomes were not figured. As a result of the research, the situations or events that will give children positive attitudes and behaviors in these cartoons in the field of motor development are almost never included. In the studied sections of 'Kuzucuk and Ege ile Gaga', none of the outcomes in motor development were found. The motor development area was only included in the 'Kare' cartoon, however it was concluded that there were only two learning outcomes in this cartoon. In all three cartoons, some learning outcomes in self-care skills are included. Considering that development as a whole and all development areas support each other, it can be said that there should be no focus on a certain development area in the behaviours that are aimed to be brought to children through cartoons. Instead, it can be thought that supporting different skills at close levels will contribute to the development of the child at the highest level. In order to support the multidimensional development of children, it is recommended that the cartoons discussed in this research are prepared in line with different learning outcomes and indicators. Since a limited number of cartoons are watched in this research, it is recommended to conduct a more comprehensive investigation by increasing the number of cartoons. Each cartoon section can be evaluated within itself and examined in a more detailed and versatile way. In addition, since a limited number of cartoon episodes are discussed in this study, factors such as the number of characters, character traits, length of the episode, and the subject of the cartoon are not considered. This situation can be accepted as the limitation of the research. It is suggested to researchers to take these factors into consideration while different studies are planned. 